amalgamation vessel, purification method of mercury, and sampling tube on the blank values were examined. Among these experimental conditions described above, only one condition, for example, surface area of the amalgamation vessel, was varied while keeping the others constant. Oxygen-free amalgam which was prepared by mixing sodium with mercury in the ratio of $1 \mathrm{~g}$ of sodium to $15 \mathrm{ml}$ of mercury and separating the oxide impurities by flotation was used as the sample for blank test. The blank value obtained under the conditions in which one variable was changed was compared with that of standard routine procedure as the reference. If significant difference was found between two blank values, it was considered that the variable contributed to a total blank.

When the inner surface area of amalgamation vessel was varied, the blank value obtained by using a large amalgamation vessel $\left(218 \mathrm{~cm}^{2}\right)$, which was used in standard routine procedure, was $8.5 \pm 0.9 \mu \mathrm{g}$ of oxygen and $6.8 \pm 1.1 \mu \mathrm{g}$ of oxygen for small one $\left(135 \mathrm{~cm}^{2}\right)$. As a result of experiments, which were shown in Table I, it was found that $4.5 \mu \mathrm{g}$ of oxygen was caused by absorbed water on inner surface of the large amalgamation vessel and $2.8 \mu \mathrm{g}$ of oxygen for the small one.

One to three $\mu \mathrm{g}$ of apparent oxygen, which may come from contamination of sodium oxide during the glove box operation, was also observed when the standard procedure was performed by carrying only mercury instead of oxygen-free amalgam through the entire procedure.

On the other hand, Tables II and III showed that argon atmosphere containing no more than $1 \mathrm{ppm}$ each of moisture and oxygen did not contribute to blank value, but when oxygen-free amalgam was treated under argon atmosphere containing 7 and $\sim 40 \mathrm{ppm}$ of moisture and oxygen, respectively, the blank increased threefold.

Effects of purification methods of mercury, i.e., distillation and filtration, and also of drying method of amalgamation vessels on the blank values were not serious as shown in Tables IV and V. Apparent oxygen from stainless steel sampling tube was measured by adding an empty sampling tube into oxygen-free amalgam and was found to be less than $0.5 \mu \mathrm{g}$ of oxygen per $12.7 \phi \times 15 \mathrm{~mm}$ stainless tube which can contain $1 \mathrm{~g}$ of sodium.

The blank value obtained by intercept method agreed well with that by using oxygen-free amalgam. However, in actual analysis it was advisable to measure the blank value by using oxygen-free amalgam because of possible segregation of oxygen in sodium.

(Received Dec. 3, 1971)

\title{
充てん剂混合法ガスクロマトグラフィーと固定相液混合法 ガスクロマトグラフィーの比較*
}

$$
\text { 三戸岡 憑 之** }
$$

(1971 年 12 月 6 日受理)

\begin{abstract}
相互溶解性のよい極性の異なった 2 種類の液相を均一に混合したのち，これを担体に含浸させる固定 相液混合法ガスクロマトグラフィーと, 単一液相を含浸させて調製した 2 種類の充てえ剂を混合する充 てえ刻混合法ガスクロマトグラフィーを，種々の液相と溶質を用いて比較検討した．その結果，極性の 低い二つの液相の組み合わせでは両法に顕著な差は認められず同様に取り扱いうるが，二つの液相の極 性が高くなるにしたがって特に固定相液混合法における有極性溶質の保持值が充てえ剂混合法における よりも低くなる傾向が認められ，これは二つの高極性液相を均一に混合することによって生じた液相分 子間相互作用が溶質保持を減少させる方向に働くためと考えられた. カラム効率やテーリング防止効 果については両法とも同様の傾向を示した. また，スクアラン/テトラクロルフタル酸ジーn-プロピル (DPTCP) 混合系を用いて芳香族炭化水素-DPTCP 分子化合物の安定度定数を測定したが，この場合 も充てえ剂混合法と固定相液混合法とは同様に取り扱うことができた.
\end{abstract}

* 混合固定相によるガスクロマトグラフィーに関する研究 (第 12, 報). 前報は三戸网憑之 : 本誌，21，729 (1972)

** 丸善石油株式会社中央研究所 : 埼玉県北葛飾郡幸手町 


\section{1 緒旁}

極性の異なった固定相液 2 種類を組み合わせたガスク ロマトグラフィーは，その組み合わせ比率を変えること によって二つの液相の中間の極性を有したカラムを任意 に調製することが可能であり，目的成分の分離にかなっ たカラムの作製が容易なことを特徵とする．液相の組み 合わせには， 2 種類の充てえ郕を任意の長さの 2 本の管 に充てえし，これを直列に接続するカラム接続法，2 種 類の充てえ郕を任意の割合に混合しこれを 1 本の管に充 てえする充てえ戍混合法，および 2 種類の固定相液をあ らかじめ任意の割合に混合しこれを担体に含浸させた充 てん剤を 1 本の管に充てえする固定相液混合法の三つが ある.このうちカラム接続法では接続順序が異なるとカ ラム内での圧力降下の差異によってピークの流出順序が 異なることがある1)-3)。しかし充てえ郕混合法と固定相 液混合法とは，二つの固定相液分子間に生ずる相互作用 が液相の溶解にのみあずかり，ぬた溶質の存在が液相の 相互作用になんら影響を及ぼさないかぎり，熱力学的に はまったく等価であるとされている4)。

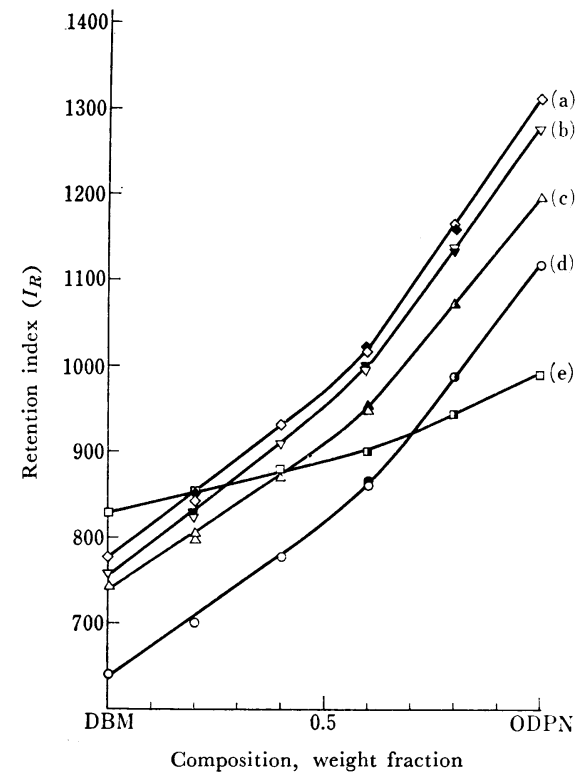

Fig. 1 Relationship between the retention index of aliphatic oxygen compounds and the composition (weight fraction) of the mixed stationary phase $\mathrm{DBM} / \mathrm{ODPN}$ at $50^{\circ} \mathrm{C}$

(a) n-Propyl alcohol; (b) Methyl ethyl ketone; (c) Ethyl acetate; (d) Propionaldehyde; (e) sec-Butyl ether; $\bigcirc$ Mixed packing method; Mixed liquid method
著者はこれ⿱で主として充てん威混合法ガスクロマト グラフィーについて研究し，各溶質の保持指標と固定相 混合組成との間に近似的に直線関係がなりたつことを明 らかにした5７．しかしこの関倸を充てん剂混合法と固 定相液混合法について調べてみると，場合によっては両 法における保持指標にわずかながら違いのあることが明 らかになった，そこで本報では，充てえ剂混合法と固定 相液混合法のそれぞれが実用上どのような差異や特徵を もち，またその差異の原因は何かを明らかにする目的 で，相互溶解性のよい種々の液相の組み合わせにおける 多くの溶質の保持挙動やカラム効率ならびにテーリング 防止効果などを調べ両法を比較した。また固定相液混合 法と同様にして充てん剂混合法により分子化合物の安定 度定数の測定も試みたのでこれらの結果を報告する.

\section{2 実験および結果}

\section{1 ガスクロマトグラフ}

水素炎イオン化型検出器を備えた日立製作所製 K53 型ガスクロマトグラフを使用した。なおキャリヤーガス にはボンベ入り乾燥へリウムを用いた。

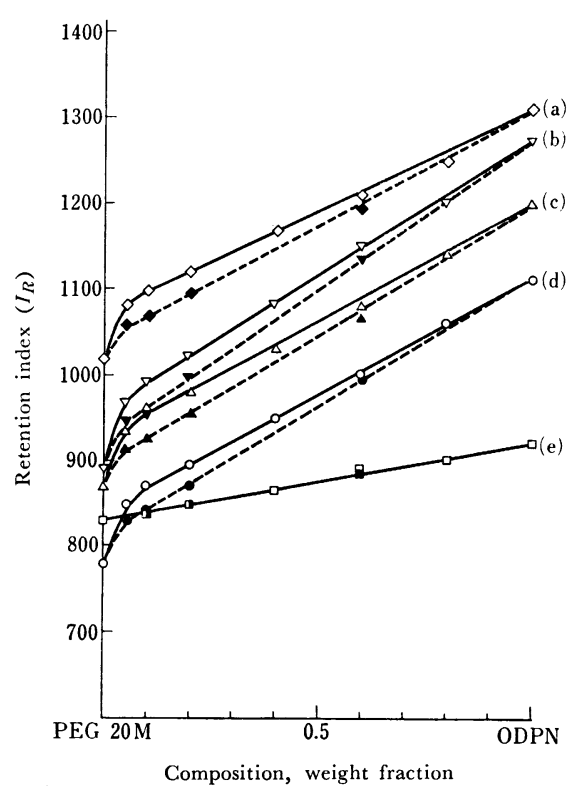

Fig. 2 Relationship between the retention index of aliphatic oxygen compounds and the composition (weight fraction) of the mixed stationary phase PEG $20 \mathrm{M} / \mathrm{ODPN}$ at $50^{\circ} \mathrm{C}$ (a) $n$-Propyl alcohol; (b) Methyl ethyl ketone; (c) Ethyl acetate; (d) Propionaldehyde; (e) Octene-1; $\bigcirc$ Mixed packing method; 1 Mixed liquid method 


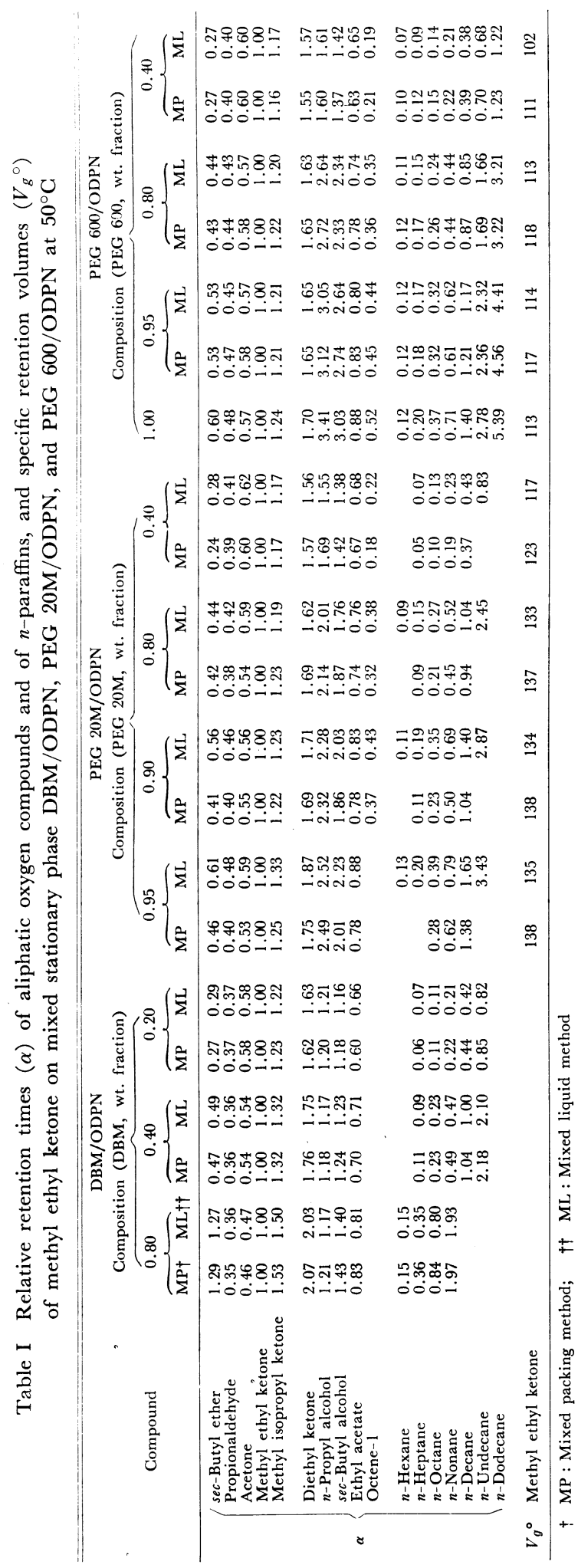

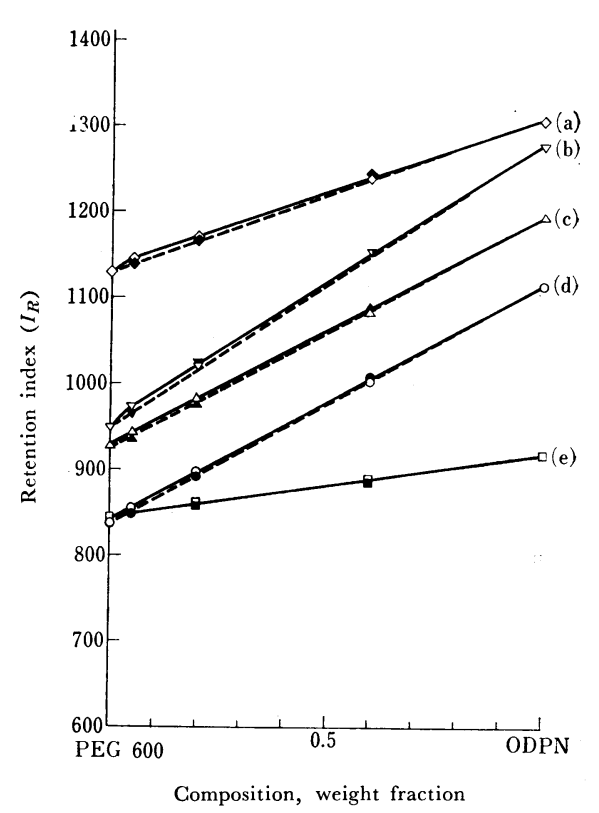

Fig. 3 Relationship between the retention index of aliphatic oxygen compounds and the composition (weight fraction) of the mixed stationary phase PEG $600 / \mathrm{ODPN}$ at $50^{\circ} \mathrm{C}$

(a) $n$-Propyl alcohol; (b) Methyl ethyl ketone; (c) Ethyl acetate; (d) Propionaldehyde; (e) Octene-1; O Mixed packing method; Mixed liquid method

\section{2 充てん剛ならびにカラムの調製}

2.2.1 固定相液 スクアラン $(\mathrm{SQ}$, 和光純薬 製), テトラクロルフタル酸ジーn-プロピル (DPTCP, ガスクロ工業製)，マレイン酸ジブチル (DBM，和 光純薬製), フタル酸ジノニル (DNP, May \& Baker 社製)，リン酸トリクレジル (TCP, 日本ク ロマト工業製), ポリエチレングリコール 600 (PEG 600, 片山化学工業製), ポリエチレングリコール 20M（PEG 20M，西尾工業製） 1, 2, 3-トリス (2シアノェトキシ) プロパン (TCEP, 日本クロマト 工業製）および $\beta, \beta^{\prime}$-オキシジプロピオニトリル (ODPN, Eastman Organic Chemicals 製) を固定 相液とし，ぞのような割合にでも均一に溶解し合う SQ/DPTCP, SQ/DNP, DNP/TCP, TGP/PEG 600, PEG 600/TCEP, DBM/ODPN, PEG 20M/ ODPN, PEG 600/ODPN の 8 種の組み合わせ混 合系を実験に用いた。

2.2.2 充てん郕混合法によるカラムの調製 ，前 項の 9 種の単一固定相液をそれぞれ HMDS 処理し 
Table II Specific retention vslumes $\left(V_{g}{ }^{\circ}\right)$ of various compounds on mixed stationary phase SQ/DNP, DNP/TCP, TCP/PEG 600, and PEG $600 / \mathrm{TCEP}$ at $100^{\circ} \mathrm{C}$

Part 1

\begin{tabular}{|c|c|c|c|c|c|c|c|c|c|c|c|c|}
\hline \multirow{3}{*}{ Compound } & \multicolumn{6}{|c|}{$\begin{array}{c}\text { SQ/DNP } \\
\text { Composition (SQ, wt. fraction) }\end{array}$} & \multicolumn{6}{|c|}{$\begin{array}{c}\text { DNP/TCP } \\
\text { Composition (DNP, wt. fraction) }\end{array}$} \\
\hline & \multicolumn{2}{|c|}{$\underbrace{0.80}$} & \multicolumn{2}{|c|}{0.50} & \multicolumn{2}{|c|}{$\overbrace{}^{0.20}$} & \multicolumn{2}{|c|}{0.80} & \multicolumn{2}{|c|}{0.50} & \multicolumn{2}{|c|}{0.20} \\
\hline & $\begin{array}{l}V_{g}^{\circ} \\
(\mathrm{MP}) \dagger\end{array}$ & $\begin{array}{l}V_{g}^{\circ} \\
(\mathrm{ML}) \dagger \dagger\end{array}$ & $\begin{array}{l}V_{g}^{\circ} \\
(\mathrm{MP})\end{array}$ & $\begin{array}{l}V_{g^{\circ}}^{\circ} \\
(M L)\end{array}$ & $\begin{array}{l}V_{g}^{\circ} \\
(\mathrm{MP})\end{array}$ & $\begin{array}{l}V_{g}^{\circ} \\
(M L)\end{array}$ & $\begin{array}{l}V_{g}^{\circ} \\
(\mathrm{MP})\end{array}$ & $\begin{array}{l}V_{g}^{\circ} \\
(\mathrm{ML})\end{array}$ & $\begin{array}{l}V_{g}^{\circ} \\
(\mathrm{MP})\end{array}$ & $\begin{array}{l}V_{g^{\circ}}^{\circ} \\
(\mathrm{ML})\end{array}$ & $\begin{array}{l}V_{g}^{\circ} \\
(\mathrm{MP})\end{array}$ & $\begin{array}{l}V_{g}^{\circ} \\
(\mathrm{ML})\end{array}$ \\
\hline$n$-Heptaldehyde & 360 & 345 & 419 & 413 & 482 & 464 & 441 & 450 & 411 & 453 & 378 & 413 \\
\hline Methyl $n$-pentyl ketone & 326 & 321 & 380 & 375 & 443 & 427 & 405 & 419 & 385 & 428 & 367 & 394 \\
\hline$n$-Hexyl alcohol & 303 & 298 & 382 & 386 & 488 & 476 & 470 & 515 & 485 & 553 & 477 & 545 \\
\hline$n-$ Hexyl bromide & 538 & 549 & 560 & 554 & 567 & 552 & 459 & 473 & 445 & 450 & 343 & 390 \\
\hline Methyl caproate & 378 & 379 & 417 & 418 & 470 & 462 & 409 & 421 & 373 & 410 & 338 & 369 \\
\hline Cyclohexanone & 342 & 336 & 429 & 424 & 524 & 506 & 518 & 538 & 535 & 582 & 546 & 586 \\
\hline Cyclohexanol & 365 & 361 & 456 & 454 & 554 & 536 & 548 & 583 & 577 & 644 & 597 & 654 \\
\hline Benza'dehyde & 588 & 558 & 777 & 767 & 1010 & 959 & 1065 & 1120 & 1130 & 1245 & 1220 & 1315 \\
\hline Acetophenone & 1280 & 1225 & 1700 & 1700 & 2185 & 2090 & 2280 & 2430 & 2420 & 2675 & 2560 & 2805 \\
\hline Benzylalcohol & 1150 & 1060 & 1795 & 1765 & 2530 & 2435 & 3045 & 3220 & 3610 & 3960 & 4180 & 4580 \\
\hline Phenol & 974 & 850 & 1835 & 1780 & 3015 & 2885 & 4745 & 4815 & 6650 & 6780 & 8350 & 8915 \\
\hline Ethoxybenzene & 730 & 713 & 837 & 847 & 945 & 903 & 853 & 900 & 826 & 920 & 829 & 891 \\
\hline Chlorobenzene & 278 & 276 & 315 & 309 & 340 & 328 & 297 & 324 & 284 & 321 & 285 & 308 \\
\hline Aniline & 691 & 664 & 1032 & 1020 & 1460 & 1410 & 1625 & 1770 & 1860 & 2060 & 2000 & 2260 \\
\hline Benzene & 76.8 & 72.2 & 75.5 & 71.7 & 81.0 & 76.9 & 69.1 & 70.9 & 71.2 & 70.2 & 52.6 & 69.3 \\
\hline Ethylbenzene & 319 & 305 & 326 & 320 & 340 & 313 & 266 & 288 & 250 & 264 & 223 & 258 \\
\hline$n$-Butylbenzene & 1290 & 1270 & 1300 & 1290 & 1325 & 1275 & 1035 & 1110 & 947 & 1040 & 800 & 923 \\
\hline$n$-Hexane & 49.0 & 51.6 & 44.9 & 45.6 & & & & & & & & \\
\hline$n$-Heptane & 97.8 & 95.5 & 84.4 & 88.8 & 74.5 & 67.0 & 47.2 & 54.7 & 36.2 & 45.0 & & \\
\hline$n$-Octane & 206 & 207 & 177 & 176 & 157 & 137 & 95.8 & 105 & 72.6 & 86.5 & 57.5 & 64.3 \\
\hline$n$-Nonane & 429 & 422 & 369 & 370 & 315 & 296 & 197 & 214 & 150 & 172 & 111 & 124 \\
\hline$n$-Decane & 896 & 895 & 777 & 763 & 655 & 626 & 407 & 428 & 306 & 343 & 221 & 244 \\
\hline$n$-Undecane & 1885 & 1880 & 1615 & 1615 & 1360 & 1305 & 822 & 860 & 624 & 685 & 440 & 436 \\
\hline$n$-Dodecane & & & 3395 & 3360 & 2790 & 2690 & 1675 & 1750 & 1260 & 1360 & 866 & 953 \\
\hline$n$-Tridecane & & & & & & & 3380 & 3555 & 2510 & 2740 & 1700 & 1875 \\
\hline$n$-Tetradecane & & & & & & & 6810 & 7120 & 5100 & 5420 & 3340 & 3730 \\
\hline$n$-Pentadecane & W & & & & & & & & & & 6650 & 7375 \\
\hline
\end{tabular}

たクロモソーブ W (30〜60 メッシュ, Johns-Manville 社製）に 20 重量\%含浸させて単一液相充てん剂を調製 し，前項に記した 8 種の組み合わせについて，おのおの の単一液相充てん剤の所定量をビーカーに採取してよく かき混ぜ，これを長さ $1 \sim 2 \mathrm{~m}$, 内径 $3 \mathrm{~mm}$ のステンレ ス管に詰めてカラムを調製した.

\subsection{3 固定相液混合法によるカラムの調製 $2 \cdot 2 \cdot 1$} に記した 8 種の組み合わせのそれぞれについて, 各液体 を所定の重量比にビーカーに採取し，均一に混合したの ち, 液相量が 20 重量\%になるように HMDS 処理した クロモソーブ W (30〜60 メッシュ) に含浸させて充て ん剤を調製し，これを長さ $1 \sim 2 \mathrm{~m}$, 内径 $3 \mathrm{~mm}$ のステ ンレス管に詰めてカラムを調製した・

\section{3 保持データの測定}

2.2 で調製したカラムを用い，DBM/ODPN， PEG 20M/ODPN および PEG 600/ODPN 混合系では $50^{\circ} \mathrm{C}$
で $\mathrm{C}_{3} \sim \mathrm{C}_{8}$ 脂肪族酸素化合物と $n$-パラフィン類の保持 時間を測定した，また SQ/DNP，DNP/TCP，TCP/ PEG 600 および PEG 600/TCEP 混合系では $100^{\circ} \mathrm{C}$ で $\mathrm{C}_{6} \sim \mathrm{C}_{7}$ 脂肪族酸素またはハロゲン化合物， $\mathrm{C}_{6} \sim \mathrm{C}_{8}$ 芳香族酸素，窒素または八ロゲン化合物， $\mathrm{C}_{6} \sim \mathrm{C}_{10}$ 芳香 族炭化水素および $n$-パラフィンなど種々のタイプの代 表的化合物の保持時間を測定した. そして SQ/DPTCP 混合系では $80^{\circ} \mathrm{C}$ で $\mathrm{C}_{6} \sim \mathrm{C}_{10}$ 芳香族炭化水素と $n$-パラ フィン類の保持時間を測定した. これらの值から，各混 合系における各溶質成分の相対保持時間 $(\alpha)$, 比保持容 量 $\left(V_{g}{ }^{\circ}\right)$ または分配係数 $(K)$ を計算した。Table I〜 III にこれらの結果を示した。

$$
3 \text { 考察 }
$$

Table I および既報5)の保持データから $\mathrm{C}_{3} \sim \mathrm{C}_{8}$ 脂肪 族酸素化合物代表成分の保持指標を求め混合組成に対し てプロットした結果を Fig. 1〜3 に示した. 同一条件に 


\begin{tabular}{|c|c|c|c|c|c|c|c|c|c|c|c|c|}
\hline \multirow{3}{*}{ Compound } & \multicolumn{5}{|c|}{$\begin{array}{c}\text { TCP/PEG } 600 \\
\text { Composition (TCP, wt. fraction) }\end{array}$} & \multicolumn{7}{|c|}{$\begin{array}{c}\text { PEG 600/TCEP } \\
\text { Composition (PEG 600, wt. fraction) }\end{array}$} \\
\hline & \multicolumn{2}{|c|}{0.80} & \multicolumn{2}{|c|}{0.50} & \multicolumn{2}{|c|}{0.20} & \multicolumn{2}{|c|}{0.80} & \multicolumn{2}{|c|}{0.50} & \multicolumn{2}{|c|}{0.20} \\
\hline & $\begin{array}{l}V_{g}^{\circ} \\
(\mathrm{MP})\end{array}$ & $\begin{array}{c}V_{g}^{\circ} \\
(\mathrm{ML})\end{array}$ & $\begin{array}{l}V_{g}^{\circ} \\
(\mathrm{MP})\end{array}$ & $\begin{array}{l}V_{g}^{\circ} \\
(\mathrm{ML})\end{array}$ & $\begin{array}{l}V_{g}^{\circ} \\
(\mathrm{MP})\end{array}$ & $\begin{array}{l}V_{g}^{\circ} \\
(\mathrm{ML})\end{array}$ & $\begin{array}{l}V_{g}^{\circ} \\
(\mathrm{MP})\end{array}$ & $\begin{array}{l}V_{g}^{\circ} \\
(\mathrm{ML})\end{array}$ & $\begin{array}{l}V_{g}^{\circ} \\
(\mathrm{MP})\end{array}$ & $\begin{array}{l}V_{g}^{\circ} \\
(\mathrm{ML})\end{array}$ & $\begin{array}{l}V_{g}^{\circ} \\
(\mathrm{MP})\end{array}$ & $\begin{array}{c}V_{g}^{\circ} \\
(\mathrm{ML})\end{array}$ \\
\hline$n$-Heptaldehyde & 331 & 322 & 255 & 263 & 214 & 220 & 184 & 175 & 173 & 142 & 155 & 123 \\
\hline Methyl $n$-pentyl ketone & 312 & 318 & 264 & 263 & 220 & 223 & 196 & 187 & 190 & 165 & 177 & 139 \\
\hline$n$-Hexyl alcohol & 553 & 533 & 555 & 569 & 564 & 576 & 505 & 479 & 416 & 340 & 328 & 300 \\
\hline$n$-Hexyl bromide & 292 & 268 & 219 & 210 & 167 & 164 & 129 & 117 & 105 & 83.4 & 83.8 & 63.2 \\
\hline Methyl caproate & 295 & 291 & 241 & 245 & 200 & 199 & 167 & 157 & 150 & 125 & 123 & 101 \\
\hline Cyclohexanone & 544 & 537 & 477 & 493 & 437 & 428 & 447 & 448 & 475 & 393 & 477 & 461 \\
\hline Cyclohexanol & 692 & 690 & 720 & 738 & 756 & 755 & 712 & 647 & 620 & 497 & 522 & 502 \\
\hline Benzaldehyde & 1295 & 1280 & 1215 & 1235 & 1185 & 1195 & 1230 & 1130 & 1165 & 1030 & 1105 & 981 \\
\hline Acetophenone & 2715 & 2695 & 2490 & 2540 & 2360 & 2410 & 2420 & 2265 & 2330 & 2140 & 2295 & 2015 \\
\hline Benzylalcohol & 5870 & 5790 & 6995 & 7120 & 8195 & 8290 & 8920 & 8255 & 7835 & 7115 & 7375 & 6220 \\
\hline Phenol & 12220 & 11650 & 14000 & 13995 & 16220 & 16085 & 16520 & 15170 & 13040 & 11760 & 10490 & 9250 \\
\hline Ethoxybenzene & 774 & 763 & 643 & 662 & 569 & 567 & 499 & 445 & 428 & 395 & 380 & 334 \\
\hline Chlorobenzene & 264 & 257 & 222 & 241 & 212 & 211 & 179 & 175 & 146 & 144 & 126 & 109 \\
\hline Aniline & 2795 & 2735 & 3275 & 3295 & 3875 & 3910 & 4450 & 4070 & 4095 & 3695 & 3885 & 3405 \\
\hline Benzene & 59.8 & 52.7 & 56.0 & 54.2 & 56.0 & 51.5 & 48.5 & 42.0 & 45.8 & 35.2 & 42.4 & 31.9 \\
\hline Ethylbenzene & 206 & 194 & 163 & 177 & 145 & 136 & 118 & 107 & 106 & 78.3 & 88.3 & 68.2 \\
\hline$n$-Butylbenzene & 684 & 665 & 517 & 524 & 410 & 408 & 296 & 274 & 236 & 192 & 191 & 147 \\
\hline$n$-Octane & 44.3 & 37.8 & & & & & & & & & & \\
\hline$n$-Nonane & 83.2 & 73.8 & 50.0 & 51.8 & 35.2 & 42.1 & & & & & & \\
\hline$n$-Decane & 151 & 139 & 92.6 & 94.3 & 62.6 & 70.3 & 39.4 & 39.7 & & & & \\
\hline$n$-Undecane & 286 & 268 & 180 & 179 & 112 & 117 & 63.8 & 62.4 & 44.1 & 37.2 & 32.3 & 23.0 \\
\hline$n$-Dodecane & 542 & 523 & 329 & 329 & 200 & 206 & 107 & 99.7 & 71.2 & 57.2 & 48.8 & 35.6 \\
\hline$n$-Tridecane & 1035 & 995 & 622 & 601 & 358 & 367 & 179 & 168 & 114 & 93.4 & 77.4 & 57.1 \\
\hline$n$-Tetradecane & 1980 & 1900 & 1160 & 1115 & 641 & 654 & 304 & 283 & 186 & 157 & 124 & 98.7 \\
\hline$n$-Pentadecane & 3730 & 3645 & 2130 & 2075 & 1135 & 1195 & 538 & 503 & 317 & 260 & 218 & 170 \\
\hline$n$-Hexadecane & 7125 & 7010 & 3960 & 3890 & 2010 & 2150 & 919 & 870 & 521 & 453 & 375 & 320 \\
\hline
\end{tabular}

おける保持指標測定のくりかえしの再現性は $\pm 8_{\text {I.U. (約 }}$ $\pm 1 \%$ ）以下でよく一致するので8), 充てえ剤混合法と固 定相液混合法の間にこれ以上の保持指標差が認められる ならば，両法は有意な差をもつと判断される.

DBM/ODPN 混合系では, 充てん剂混合法と固定相 液混合法とにおける保持指標はよく一致している. この ことはまた Table I の相対保持時間の比較からも明ら かである. 一方, PEG 20M/ODPN 混合系では, 固定 相液混合法における保持指標が充てん剂混合法における よりも低い值を示し, PEG 20M 混合率の高い, いわゆ る低極性側領域においてその傾向が強い. オクテン-1 についてはいずれの方法においても保持指標に差は認め られない. PEG 20M よりも極性の高い PEG 600 を組 み合わせた PEG 600/ODPN 混合系では, Fig. 3 から 明らかなように, 充てん剂混合法と固定相液混合法とに おける保持指標の差は PEG 20M/ODPN 混合系の場合 ほど顕著でない. しかし Table I に示した保持データ によると, 両法の比保持容量には若干の差が認められ, 固定相液混合法における比保持容量は充てん剂混合法に おけるよりも小さい. そしてまたこの傾向は極性の高い
液相の組み合わせほど強いことがわかる.

極性の差のそれほど大きくない二つの液相は相互溶解 性がよい7). 極性の異なった多くの固定相液のなかから， 相互溶解性のよい 4 種の組み合わせ混合系 (SQ/DNP, DNP/TCP，TGP/PEG 600, および PEG 600/TGEP) を選び，若香族化合物を溶質に用いて液相の極性の違い に基づく充てえ剂混合法と固定相液混合法との間の差異 を調べたＳQを0，TGEPを 100 としたとき，この 実験で用いた各液相の相対極性は DNP 21, TCP 41, そして PEG 60069 である?. Table II および既報》 の保持データから求めた代表成分の保持指標を各混合系 の混合組成に対してプロットした結果を Fig. 4 (1)〜 (8) に示した.

四つの組み合わせのうち最も極性の低いSQ/DNP 混 合系では, SQ 0.80 重量分率付近で, 充てえ刘混合法 におけるフェノールの保持指標が固定相液混合法におけ るそれよりも約 20I.U. 大きい以外は，両法におけるい ずれの成分の保持指標もほとんどよく一致している. ま たこれよりも少し極性の高い DNP/TCP 混合系におい てもよい一致が認められる. これに対して極性の高い組 

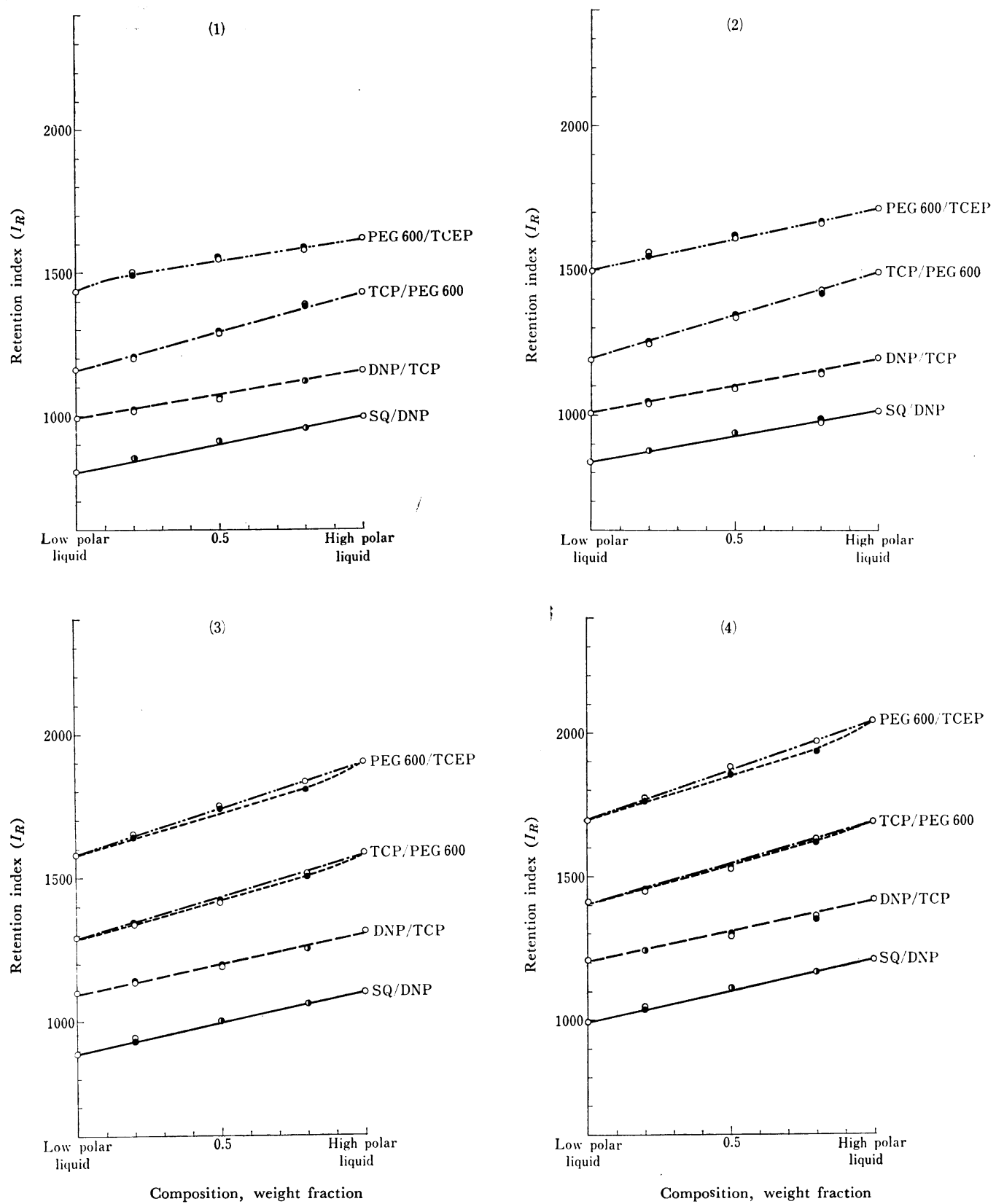

Fig. 4 Relationship between the retention index of the solute and the composition (weight (1) $n$-Hexyl alcohol; (2) Cyclohexanol; (3) Benzaldehyde; (4) Acetophenone; (5) Benzyl alcohol ; - - - PEG/TCEP; O Mixed packing method; 1 Mixed liquid method

み合わせになると，特に芳香族酸素および窒素化合物に おいて両者が一致しなくなる傾向にある。すなわち，フ ェノールやアニリンの固定相液混合法における保持指標 は充てえ剤混合法に扮けるよりも小さくなり，その傾 向は TCP/PEG 600 混合系より極性の高い PEG 600/
TCEP 混合系においてより顕著である.また一つの混 合系においても固定相の相対極性が高くなるほどその傾 向は強い.

Table II の比保持容量を両法について比較すると， 相対極性の高い組み合わせほど固定相液混合法における 

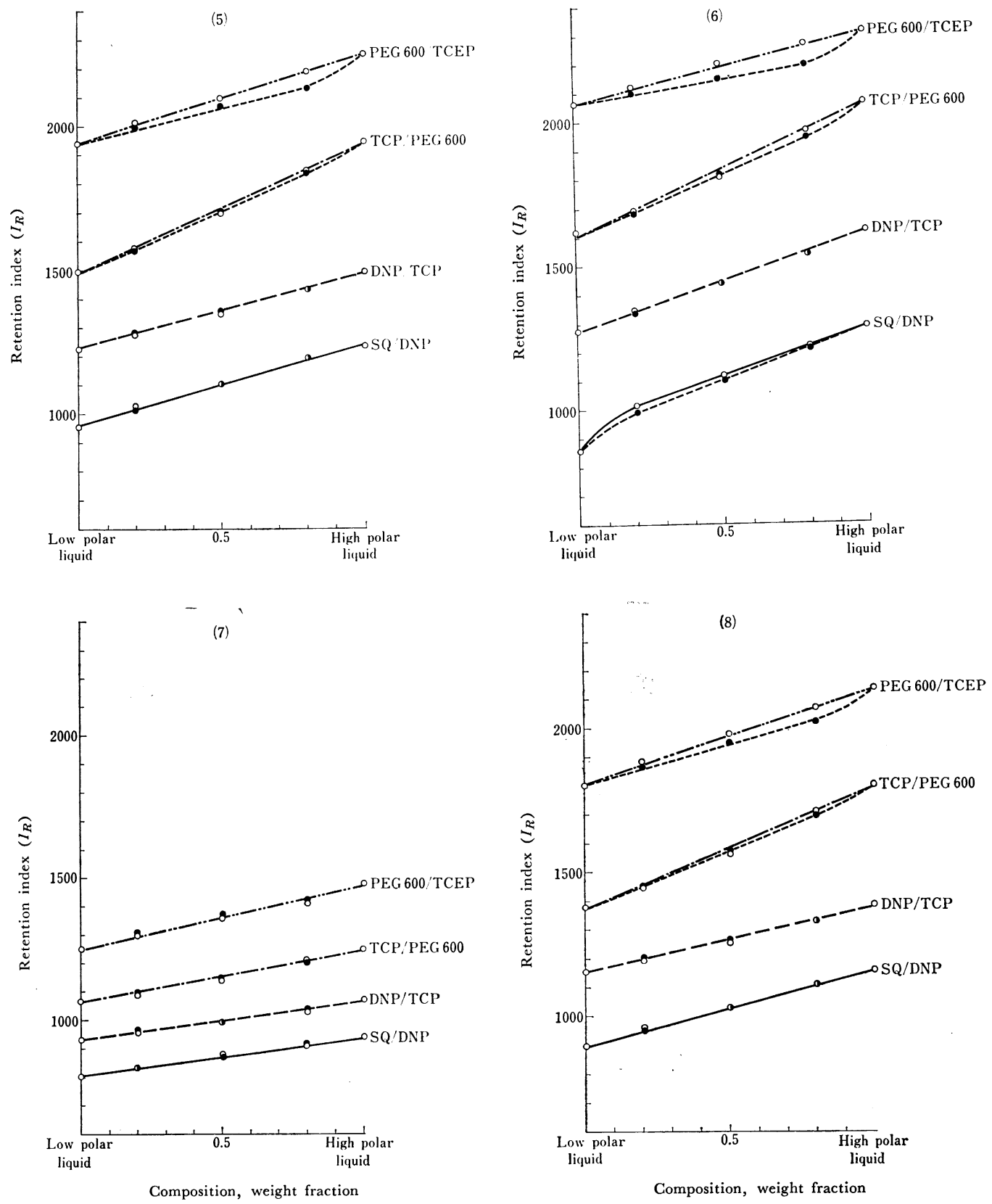

fraction) of the mixed stationary phase at $100^{\circ} \mathrm{C}$
(6) Phenol;
(7) Chlorobenzene;
(8) Aniline;
- SQ/DNP;
- - DNP/TCP; - - - TCP/PEG ;

比保持容量が充てえ剂混合法におけるよりも小さくなる というさきに PEG/ODPN 混合系で指摘した傾向がさ らに明らかである。 また $n$-パラフィン類よりも有極性 化合物のほうが一般に減少の傾向が顕著である. 両法の 間に生ずる保持指標の差は，このように溶質によって比
保持容量の減少度が 違うことに基づくものと考觉られ る. また保持指標の差が小さくても比保持容量にかなり の差を見いだすことができる.二つつの液相の均一混合系 では, 混合率の低い液相分子 (I) は混合率の高い液相 分子 (II) によって取り囲まれていると考光られる.こ 


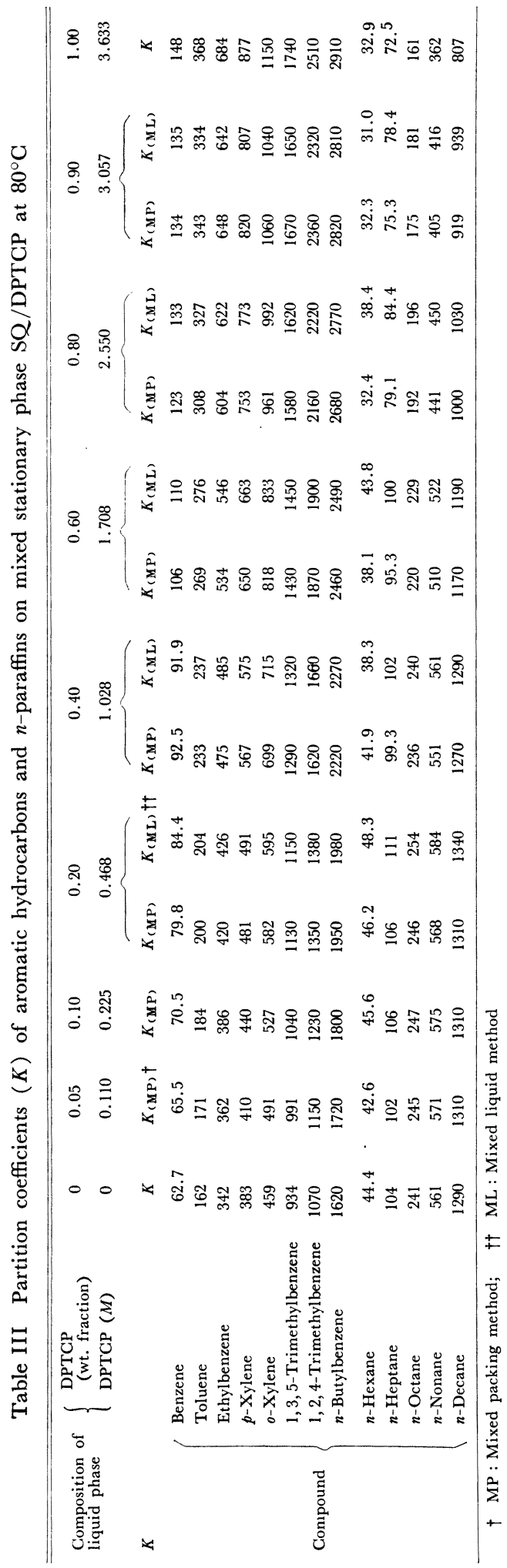

こでもしも液相分子 (I) が溶質分子に対してより親和 的であるならば, 液相分子 (II) が液相分子 (I) と溶質 分子との相互作用を阻害するであるう．また混合によっ て生ずる液相分子 (I) と (II) の間の相互作用が強けれ ば, 混合系の見かけの凝集エネルギーは増加し，したが って溶質の混合エンタルピーは正の方向に増加するであ ろう. 固定相液混合法における比保持容量が充て几剂混 合法におけるよりも小さくなるのはこのような効果に基 ゔくものと考えられる.

固定相液と溶質の問には, 配向, 誘起, 分散の三つの 効果に基づいた通常の溶解力のほかに水素結合や錯化合 物生成力が働き, 特定の溶質に対して有効な分離を与え ることがある．錯塩の生成力をクロマトグラフ分離に応 用した例として，硝酸銀によるオレフィン炭化水素の分 離910)，テトラハロフタル酸エステル11)，二トロクロル 置換ベンゼン12)-14) による芳香族炭化水素の分離がよく 知られている. 溶媒一溶質間で特殊な分子間相互作用が 生ずる場合について固定相液混合法と充てえ剂混合法と の間に有意な差があるかどうかを明らかにしておくこと は, この手法を今後さらに発展させていくうえにも重要 なことである、このような観点から，ここでは芳香族炭 化水素々 $\pi-\pi$ 電荷移動型分子化合物を形成するテトラ クロルフタル酸ジーn-プロピル (DPTCP) と無極性液相 スクアラン (SQ) との混合系について両法間の差を調 ベた.

Fig. 5 に Table III の分配俰数から計算した保持指 標の混合組成に対するプロットを示した.なお，ここで 混合固定相における分配係数の計算にあたり，いずれの 方法に拉いてもカラム内の液相の容積は二つの液相の容 積の和に等しいと仮定した ${ }^{15}$ ).

Table III および Fig. 5 からも明らかなように，SQ/ DPTCP 混合系では, 両法に沶ける分配係数ならびに保 持指標は各成分とも非常によく一致している.したがっ てこの系については充てん剤混合法と固定相液混合法は まったく等価であり, 同様の取り扱いが可能なことがわ かった。

Muhs らは硝酸銀-エチレングリコールの混合液を固 定相としてオレフィン類の気液分配係数を測定すること により，銀イオンーオレフィン錯化合物の安定度定数を 決定した ${ }^{16)}$. また著者も同様にして 2,4-ジニトロクロ ルベンゼン一芳香族炭化水素分子化合物の安定度定数を 測定した ${ }^{17}$ )。これらはいずれも固定相液混合法の一つの 応用であるが，上記のように SQ/DPTCP 系では充て え剤混合法もまったく同様に取り扱いうるので，これら のデータを用いて DPTCP-芳香族炭化水素分子化合物 


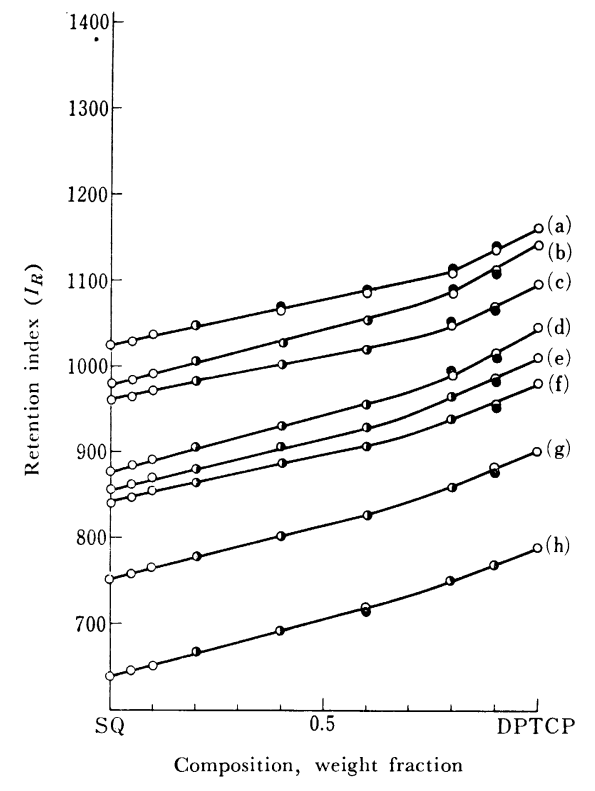

Fig. 5 Relationship between the retention index of aromatic hydrocarbons and the composition (weight fraction) of the mixed stationary phase SQ/DPTCP at $80^{\circ} \mathrm{C}$

(a) $n$-Butyl benzene; (b) 1,2,4-Trimethyl benzene ; (c) 1,3,5-Trimethyl benzene; (d) $o$-Xylene; (e) $p$ Xylene; (f) Ethyl benzene; (g) Toluene; (h) Benzene; $\bigcirc$ Mixed packing method; $\quad$ Mixed liquid method

\section{安定度定数の測定を試みた.}

今, SQ/DPTCP 混合系では, DPTCP 之芳香族炭化 水素の $1: 1$ 分子化合物生成力のみが溶質の分配係数に 影響するものと仮定する．そして Muhs らの方法と同 様にして，溶質の分配係数 $(K)$ とカラム中の DPTCP のモル濃度（[DPTCP $]_{\mathrm{L}}$ ） との関係を式（1）のように 表わした。

$$
K=K_{\mathrm{L}}+K_{1} K_{\mathrm{L}}[\mathrm{DPTCP}]_{\mathrm{L}}
$$

ここに，KL は単一液相 (SQ) における溶質の分配係 数, $K_{1}$ は分子化合物安定度定数であって, $[\mathrm{DPTCP}]_{\mathrm{L}}$ 浱度に対して分配係数（K) をプロットすれば，そのこ う配から $K_{1} K_{\mathrm{L}}$ を，てして切片から $K_{\mathrm{L}}$ を求めること ができる.

Fig. 6 亿分配倸数 $(K)$ を $[\mathrm{DPTCP}]_{\mathrm{L}}$ 濃度に対して プロットした結果を，そして Table IV にこれより求 めた分子化合物安定度定数 $\left(K_{1}\right)$ を示した. Table IV から，置换基の大きさや位置によって分子化合物の生成 に差異のあることがわかる。 また $K_{1}$ は Fig. 5 の直線

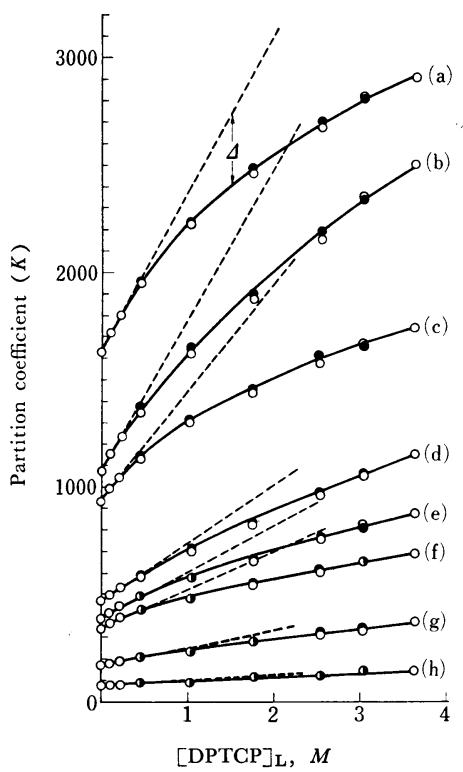

Fig. 6 Variation of partition coefficient with molarity of DPCTP for various aromatic hydrocarbons at $80^{\circ} \mathrm{C}$

(a) n-Butyl benzene, (b) 1,2,4-Trimethyl benzene; (c) 1,3,5-Trimethyl benzene; (d) $o$-Xylene; (e) $p$ Xylene; (f) Ethyl benzene; (g) Toluene; (h) Benzene; $\bigcirc$ Mixed packing method; Mixed liquid method

のこう配と類似した傾向を示すが，このことは Fig. 5 のようなプロットのこう配が分子間相互作用に関連した ものであることを立証するものである5)ー7。

Fig. 6 に2られる直線からのかたより（U）について は，Muhs らは塩析効果（溶解度抑制効果）によるもの と説明している. 固定相液混合法においてはこのような 理由づけも可能である.しかしながら充てえ剂混合法に おいてもみられる同様の傾向を塩析効果で説明すること は困難である。親和性の強い液相を少量添加すると，そ

Table IV Stability constant $\left(K_{1}\right)$ of DPTCParomatic hydrocarbon molecular compound at $80^{\circ} \mathrm{C}$

\begin{tabular}{lc}
\hline Compound & $K_{1}(1 / M)$ \\
\hline Benzene & 0.457 \\
Toluene & 0.503 \\
Ethylbenzene & 0.523 \\
$p$-Xylene & 0.571 \\
& \\
$o$-Xylene & 0.611 \\
1,3,5-Trimethylbenzene & 0.544 \\
1,2,4-Trimethylbenzene & 0.659 \\
$n$-Butylbenzene & 0.460 \\
\hline
\end{tabular}


Table V Height equivalent to theoretical plate (HETP) and degree of peak symmetry $\left(D_{s}\right)$ of typical compounds on mixed stationary phase SQ/DNP at $100^{\circ} \mathrm{C}$

\begin{tabular}{|c|c|c|c|c|c|c|c|}
\hline \multirow{3}{*}{ Method } & & \multicolumn{5}{|c|}{ Composition of liquid phase (SQ, wt. fraction) } & \\
\hline & & & & & & \multicolumn{2}{|c|}{$\overline{0.20}$} \\
\hline & & MP & ML & $\mathrm{MP}$ & ML & $\mathrm{MP}$ & ML \\
\hline HETP (mm) & $\begin{array}{l}\text { Benzaldehyde } \\
\text { Aniline } \\
n \text {-Decane }\end{array}$ & $\begin{array}{l}0.78 \\
1.01 \\
0.74\end{array}$ & $\begin{array}{l}0.75 \\
1.21 \\
0.74\end{array}$ & $\begin{array}{l}0.78 \\
1.01 \\
0.7 j\end{array}$ & $\begin{array}{l}0.73 \\
1.21 \\
0.71\end{array}$ & $\begin{array}{l}0.69 \\
0.85 \\
0.80\end{array}$ & $\begin{array}{l}0.78 \\
0.90 \\
0.76\end{array}$ \\
\hline$D_{s}$ & Phenol & 8.18 & 8.15 & 3.39 & 3.17 & 3.17 & 3.22 \\
\hline
\end{tabular}

れの溶質の保持に及ぼす効果が非常に大きいことをすで に報告したが15)，DPTCP 濃度の低いところではこの効 果がより顕著であると考えたほうがよいようである.

最後にカラムの分離効率とテーリング防止効果につい て両法を比較した． Table V に SQ/DNP 混合系にお ける代表成分の理論段相当高 (HETP) ならびにフェノ ールのピーク対称度 $\left(D_{s}\right)^{18)}$ を示した。 これから明らか なように，両法間には理論段相当高の差は認められな い.したがって，いずれの方法によっても同じ分離効率 のカラムを調製できることがわかった。

無極性液相充てえ剂に少量の有極性液相充てえ剂を添 加するだけで，有極性溶質のテーリングが著しく減少す る.これは，二つの充てえ剂の混合によって有極性液相 の一部が無極性液相充てえ剂に移行し，これが吸着活性 点に選択的に吸着するためであると考えられる ${ }^{18)}$. しか らば，あらかじめ二つの液相を混合して担体に塗布する と, これら吸着活性点はより完全にふさがれ，テーリン グはなおいっそう減少するであろう. Table V に示し たピーク 対称度 $\left(D_{s}\right)$ をテーリングの指標とするなら ば, 単一液相 SQ におけるフェノールの $D_{s}$ は 34.4 で あるから ${ }^{18)}$ ，当然ながら固定相液混合法にもテーリング 防止効果が認められる. しかしながら両法を比較する と, 二つはまったく同様の結果を示し，特に固定相液混 合法のほうがテーリング防止に関して有利であるとはい えない.

\section{4 結咅}

相互溶解性のよい二つの液相を組み合わせた混合系数 種を用いて，充てん剂混合法ガスクロマトグラフィーと 固定相液混合法ガスクロマトグラフィーを比較した。 そ の結果, 比較的極性の低い液相の混合系では，充てえ剂 混合法と固定相液混合法の間に，溶質保持やカラムの分 離効率に関して顕著な差は認められなかった。しかし， 極性の高い液相の組み合わせでは，特に芳香族酸素また は窒素化合物のような有極性溶質の固定相液混合法にお ける比保持容量が充てえ剤混合法におけるよりも減少す
る傾向が認められ，この場合両法にかなりの違いがある ことが明らかに汸った。これは，固定相液混合法におい て液相を均一に混合するとき新たに生じた液相分子間相 互作用が溶質の溶媒中への混合溶解を阻害し, 溶質の保 持能力を減少させる方向に働くためと推察された. 固定 相液混合法においては, 極性の高い単一液相の有与る溶 質保持特性が，他の液相を混合することによって失わ れ，溶質の分離にじゅうぶんに生かし光ない場合のある ことが明らかになった。

これに比べて，充てん用混合法では二つの液相がブロ ック状に存在するため液相分子間に新たな相互作用が生 ずる確率は低く，それに基づく溶質保持の变化はほとえ ど無視される．そのために充てん剂混合法では単一液相 のもつ保持特性をそのまま生かすことが可能である. たこの方法にはカラム充てん剤の調製がきわめて簢単な ことなどの特徵がある. 充てん剂混合法と固定相液混合 法とはカラム効率やテーリング防止効果に関しては同㥞 の結果を示す．しかし前述の特徵を考え合わせると，充 てえ剤混合法は固定相液混合法よりもかなり実用的であ るといえる。

終わりに，本研究を行なうにあたって終始有益なご示 唆と懇切なご指導を賜わった京都大学工学部舟阪 渡教 授, 丸善石油株式会社常務取締役雨宮登三，取締役上势 常英，三宅 坦，大島昌三の各氏に深謝します。

\section{交献}

1) M. Singliar, A. Bodak, J. Birda, L. Lukacovic : Z. anal. Chem., 177, 161 (1960).

2) H. J. Maier, O. G. Karpathy : J. Chromatog., 8, 308 (1962).

3) G. P. Hildebrand, C. N. Reilley : Anal. Chem., 36, 47 (1964).

4) R. A. Keller, G. H. Stewart : ibid., 36, 1186 (1964).

5) 三戸岡恣之：本誌，20，1542 (1971).

6) 三戸岡憑之：同上，21，189 (1972).

7) 三戸岡憑之：同上, 21, 197 (1972).

8) 三戸岡恣之：同上，21，354 (1972).

9) F. van de Graats : Anal. Chim. Acta, 14, 136 (1956).

10) F. Armitage : J. Chromatog., 2, 655 (1959). 
11) S. H. Langer, C. Zahn, G. Pantazoplos : ibid., 3, 154 (1960).

12) L. G. Case : ibid., 6, 381 (1961).

13）荒木長男，後藤良造，小野 葵：日化，82，1081 (1961).

14) H. Miyake, M. Mitooka : Bull. Japan Petrol. Inst., 5, 58 (1963).

15) 三戸岡恣之：本誌，21，717 (1972).

16) M. A. Muhs, F. T. Weiss :J. Am. Chem. Soc., 84, 4697 (1962).

17）三宅 坦, 三戸阔恣之（舟阪 渡, 池川信夫編): “最新ガスクロマトグラフィーIII”, p. 152 (1971), (広川書店).

18) 三戸岡憑之：本誌，21，614 (1972).

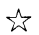

Comparison of mixed packing gas chromatography with mixed stationary liquid gas chromatography. (Studies of gas chromatography with mixed stationary phase. XII.) Mitsuyuki MiтоoкA (Research and Development Center, Maruzen Oil Co., Ltd., Satte-cho, Kitakatsushika-gun, Saitamaken)

Although the mixed packing gas chromatography (MPGC) is considered to be essentially equivalent to the mixed liquid gas chromatography (MLGC) if the stationary liquids behave ideally and they are not particularly interactive each other in the chromatographic column with a combination of two liquids of different polarity, some differences had been found in practical applications. To clarify the source of these differences, in this paper, MPGG was compared with MLGG by the examination of the retention ability, the column efficiency, or the tailing reducing effect of them using various combinations of liquids.

Squalane (SQ), di-n-propyl tetrachlorophthalate (DPTCP), dinonyl phthalate (DNP), dibutyl maleate (DBM), tricresyl phosphate (TCP), polyethylene glycol 600 (PEG 600) or 20M (PEG 20M), 1, 2, 3tris(2-cyanoethoxy)propane (TCEP), or $\beta, \beta^{\prime}$-oxydipropionitrile (ODPN) was used as a stationary liquid and out of them two miscible liquids were combined as follows : SQ/DPTCP, SQ/DNP, DNP/TCP, TCP/ PEG 600, PEG 600/TCEP, DBM/ODPN, PEG 20M /ODPN, PEG 600/ODPN. The column packing was prepared by mixing two types of packing coated with a single liquid in MPGG, or by coating a uniform mixture of two liquids on the solid support in MLGG.

On comparing the retention data obtained on various columns, it was evident that, in the combinations of low polar liquids such as SQ/DNP or DNP/TCP, there was no remarkable difference of the retention ability between MPGG and MLGG. On the other hand, in the combinations of high polar liquids such as PEG/TCEP or PEG/ODPN, MLGG had a tendency to reduce the specific retention volume of polar solutes. This reduction of retention in MLGC may be based on the fact that the interactions which arised among the liquid molecules interfered with the dissolving or mixing of solute to the mixed liquid. The difference of column efficiency or tailing reducing effect between MPGG and MLGG was not significant. In SQ/ DPTCP, where one molecule of DPTCP forms a chargetransfer molecular compound with one molecule of aromatic hydrocarbon, the partition coefficient $(K)$ of the aromatic hydrocarbon on MLGG almost agreed with $K$ on MPGC. Hence, it can be considered that the particular interaction between solute and solvent has not a remarkable effect to differ the retention of solute between MLGG and MPGG. In the same manner as Muhs et al. applied to MLGC, the stability constant of the molecular compound could be determined using $K$ on MPGG.

It is possible to make use of the characteristics of the original liquids sufficiently in MPGG because these liquids may exist independently in the column without a change in quality, but it is not so sometimes in MLGC. Moreover, as MPGC is characterized by the ease of the column preparation and by the possibility of the use of a combination of the liquids immiscible with each other, MPGC may be in superior situation to MLGG for practical usage.

(Received Dec. 6, 1971) 